This is the author's final, peer-reviewed manuscript as accepted for publication. The publisher-formatted version may be available through the publisher's web site or your institution's library.

\title{
The role of money arguments in marriage
}

Sonya L. Britt, Sandra J. Huston

\section{How to cite this manuscript}

If you make reference to this version of the manuscript, use the following information:

Britt, S. L., \& Huston, S. J. (2012). The role of money arguments in marriage. Retrieved from http://krex.ksu.edu

\section{Published Version Information}

Citation: Britt, S. L., \& Huston, S. J. (2012). The role of money arguments in marriage. Journal of Family and Economic Issues, 33(4), 464-476.

Copyright: @ Springer Science+Business Media, LLC 2012

Digital Object Identifier (DOI): doi:10.1007/s10834-012-9304-5

Publisher's Link: http://link.springer.com/article/10.1007/s10834-012-9304-5

This item was retrieved from the K-State Research Exchange (K-REx), the institutional repository of Kansas State University. K-REx is available at http://krex.ksu.edu 


\title{
The Role of Money Arguments in Marriage
}

\begin{abstract}
Despite the paucity of empirical evidence indicating the impact of money arguments on spousal relationship outcomes, it is common belief that money plays a large role in the life of couples. This study used panel data from the 1979 National Longitudinal Study of Youth (NLSY79) to examine how money-related arguments affect the marital relationship. Economic theory indicates that initial expectations about the marriage and variance in expectations are both important in predicting relationship satisfaction and divorce. Money arguments were modeled as a sign of the lack of investment in spousal-specific capital and were hypothesized to negatively impact relationship quality. Results suggest that money arguments are an important indicator of relationship satisfaction, but are not as influential in predicting divorce. Both the approach used to model money arguments and the empirical results can be used by marriage therapists and financial counselors to help couples understand and improve the benefits received through marriage.
\end{abstract}

Key Words: money arguments, divorce, relationship satisfaction, predictors 


\section{Introduction}

Research suggests that money plays a prominent role in couples' lives (e.g., Aniol \& Snyder, 1997; Stanley, Markman, \& Whitton, 2002), though financial issues appear to be a more commonly reported problem for reduced relationship satisfaction than they are a reason for divorce (Albrecht, 1979). Researchers agree that financial problems are a primary stressor for couples (Amato \& Previti, 2003; Risch, Riley, \& Lawler, 2003; Zagorsky, 2003), yet “virtually no studies exist that support the still popular belief that financial problems are the number one cause of divorce" (Andersen, 2005, p. 149). Given the high societal costs of divorce (Amato, 2000), it is essential to determine what extent money arguments predict lower relationship satisfaction, which may potentially lead to divorce or continued marriage in an unsatisfying relationship.

The frequency of arguments among couples is one of the least researched areas in the marriage and divorce literature (Amato \& Previti, 2003; Becker, 1981; White, 1990). Several studies have attempted to rank financial issues in terms of their contribution to couples' decision to divorce. In a sample of newlywed couples married five years or less, Risch et al. (2003) determined that couples ranked financial issues (which included debt brought into the marriage, employment status of partners, and financial decision making) third among 10 possible content areas as a source of conflict within their marriage. Given the increases in employment of wives, Risch et al. suggested that financial issues have the potential to continue to grow as a source of conflict for couples, particularly since couples tend to report that financial issues are not well covered during premarital counseling sessions.

Amato and Previti (2003) found financial problems to be the $13^{\text {th }}$ most commonly reported reason for divorce $(2 \%$ of sample reported financial problems as a reason for their 
divorce) out of 18 unique themes identified by the researchers. Elements from Amato and Previti's research related to money arguments included not meeting obligations (e.g., breadwinning and household work conflicts) and work problems (e.g., working too much) with $3 \%$ of the sample reporting each of these reasons as a cause for their divorce.

Dolan and Hoffman (1998) used a similar approach to Amato and Previti (2003) by asking individuals to identify whether 51 statements (grouped into the following scales: emotional support, incompatibility, career support, abuse, housework, financial problems, sexual problems, child conflicts, and child care) contributed to their decision to divorce. The five highest determinants of divorce were incompatibility, emotional support, abuse, sexual problems, and financial problems. Dew's (2009) focus was on ranking money arguments among 10 total sources of arguments as a contributing factor to divorce. He found that money arguments were the strongest of the 10 types of arguments in predicting divorce.

The purpose of this study was to determine the influence wives' reports of money arguments on relationship quality and the likelihood of divorce. Knowledge of spousal money preferences is a valuable proficiency for the couple to develop. Marriages where spouses do not invest in an awareness of spousal money preferences may experience increased money arguments leading to lower relationship satisfaction and a greater likelihood of divorce. Although the same could be said for couples experiencing lower relationship satisfaction and a greater likelihood of divorce by not developing knowledge of other spousal preferences (e.g., ideas regarding child rearing), the purpose of this paper was to determine how money arguments are influential in negative relationship outcomes to help fill the gap in the literature related to money issues within marriage. Policy implications include mandatory premarital counseling that revolves around the predictors of low relationship satisfaction and divorce. Utilizing a theory of 
marriage framework (e.g., Becker, 1981) makes it possible to identify concepts known to influence the decision to marry and stay married. From here, researchers, practitioners, and policy makers can identify ways to help consumers reduce their likelihood of experiencing a negative relationship outcome.

\section{Theoretical Framework and Related Literature}

Based on a review of the marriage and divorce literature, the factors increasing the likelihood of positive relationship outcome (i.e., higher relationship satisfaction or lower likelihood of divorce) must be greater than the factors increasing the likelihood of a negative relationship outcome (i.e., lower relationship satisfaction or increased likelihood of divorce) in order for a couple to receive utility from marriage. Couples have an incentive to remain married as long as Equation 1 remains true.

$$
E U_{M H W} \geq E U_{S H}+E U_{S W}
$$

Where $\mathrm{EU}_{M H W}$ equals the joint expected utility from marriage of a husband and wife (HW), $\mathrm{EU}_{S H}$ equals the expected utility of husband when single, and $E U_{S W}$ equals the expected utility of wife when single.

If the amount of expected net gains $[E(G)]$ from marriage and/or the variance between expected and actual net gains $[\operatorname{Var}(G)]$ are such that gains from marriage are not realized (i.e., the actual utility from marriage is less than the expected combined utility of the husband and wife when single), the probability of a negative relationship outcome (i.e., low relationship satisfaction or divorce) increases. Equation 2 shows that the probability of a negative relationship outcome $(N O)$ is a function of the level of expected net gains from marriage, $E(G)$, as well as the variation of expected gains compared to actual or realized gains from marriage, $\operatorname{Var}(G)(\operatorname{Bryant}$ \& Zick, 2006). 


$$
P(N O)=n o[E(G), \operatorname{Var}(G)]
$$

Each marriage has an expectation of gain and a distribution of uncertainty (variance) associated with that expectation (see Figure 1). The distance between 0 and $E(G)$ measures the amount of expected net gain. Assuming a normal distribution of uncertainty around this expected level, the variance in gains $[\operatorname{Var}(G)]$ shows the range of possible gains realized. This particular distribution indicates that it is more probable for the expected gains to be in close proximity, yet it is possible to greatly exceed expectations (far right tail of distribution) or to greatly underestimate gains (far left tail of distribution). Figure 1 depicts that most marriages will realize a net gain (i.e., the distribution to the right of the 0 gains threshold), while some marriages will incur negative net gains (distribution to the left of the 0 gains threshold) and be most likely to result in a divorce. Marriages that experience some gain from marriage, but less than their expected gains, will likely report a lower level of relationship satisfaction than those whose gains exceed what they expected [distribution to the right of the $E(G)$ thresehold].

\section{Figure 1}

\section{Amount and Variation of Expected Net Gains from Marriage}

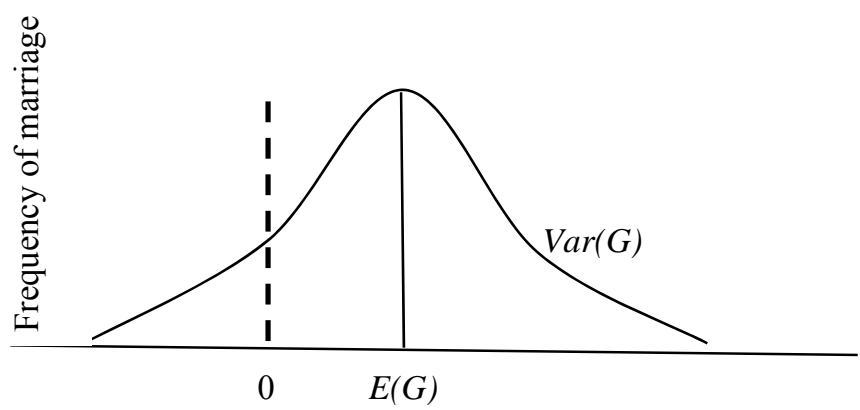

Net gains from marriage

Level of Expected Gains, $E(G)$. Couples who expect higher net gains from marriage are less likely to experience a negative outcome compared to couples who expect lower net gains 
from marriage. Holding the variance distribution constant, Figure 2 shows the difference between marriage types $\mathrm{A}$ and $\mathrm{B}$, with marriage $\mathrm{B}$ having greater expected net gains compared to marriage A.

Figure 2

Level of Expected Gains from Marriage - Constant Variance (Bryant \& Zick, 2006)

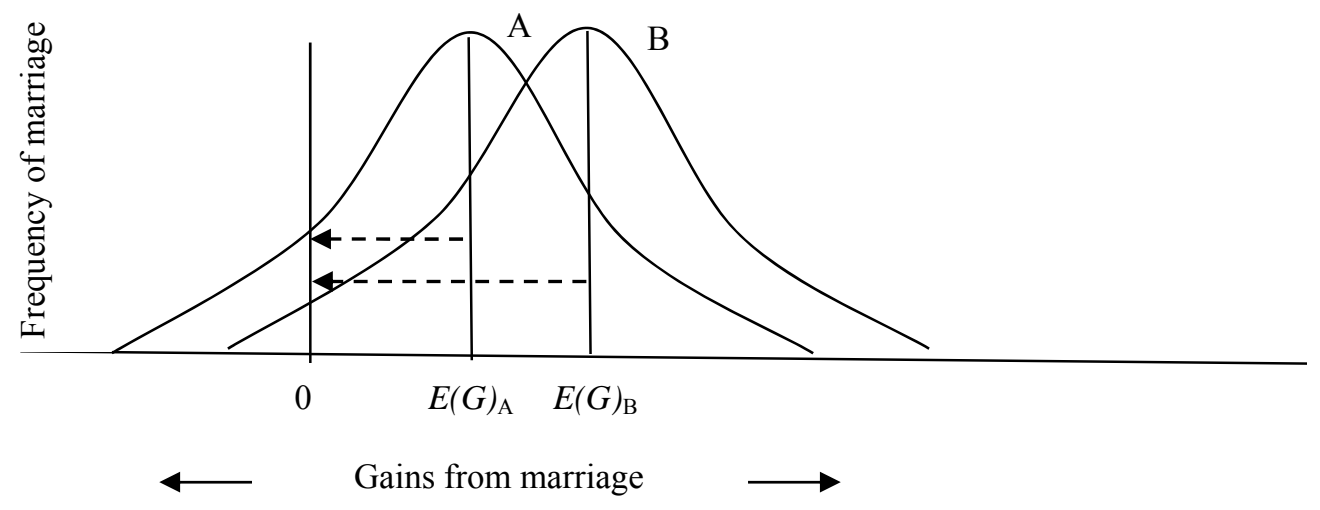

When the amount of expected net gains are more positive (i.e., further to the right from the 0 threshold - for example, marriage B), there is less distribution in the negative net gains quadrant, thus the lower the probability of a negative outcome. Marriages with lower levels of expected net gains (for example, marriage A) have a larger area under the variance curve distributed in the negative net gains quadrant and the greater the probability of divorce.

Variance in Expected Versus Actual Gains, Var(G). Couples who have greater uncertainty (a flatter and wider distribution surrounding expected net gains) regarding marriage have a higher probability of a negative outcome compared to couples who are less uncertain about realizing expected net gains from marriage. Holding the level of expected net gains constant, Figure 3 shows the difference between marriage types C and D, with marriage D having greater variance in expected net gains compared to marriage $\mathrm{C}$. 
Figure 3

Variance of Expected Gains from Marriage - Level Constant (Bryant \& Zick, 2006)

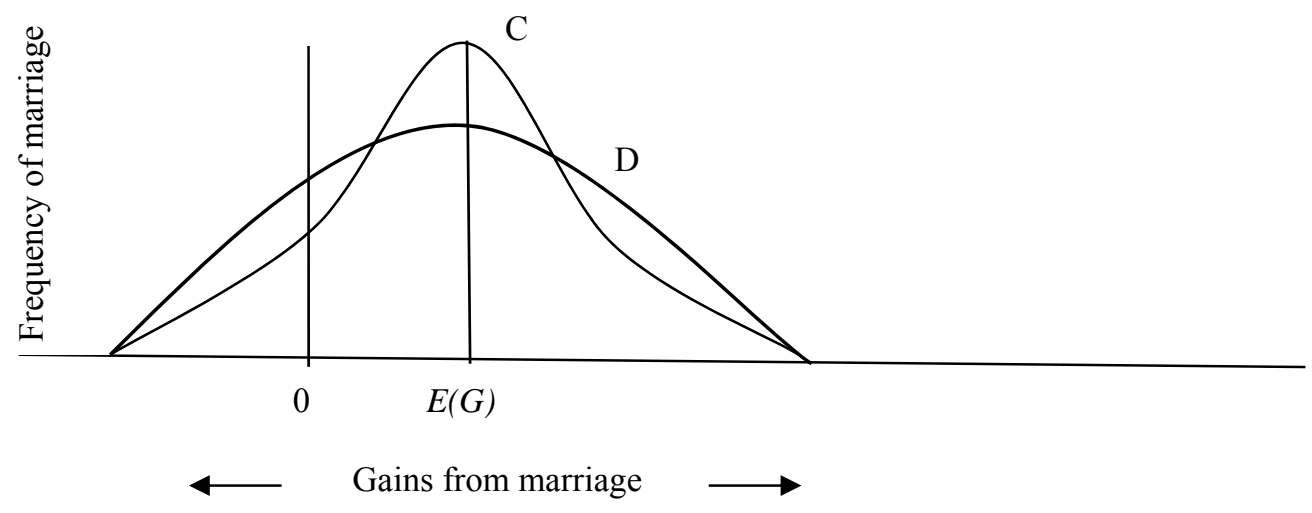

Bryant and Zick (2006) summarized the factors influencing expected and variance in

gains as (a) spousal-specific investments, (b) spousal search activity, and (c) assortative mating, which are explored in the following sections.

Spousal-Specific Investments

Spousal-specific investments are investments of time and energy from both spouses which increase the gains from marriage, but cannot be transferred to another relationship. There are a number of factors that are specific to a couple that do not have the same effect when transferred to a different relationship, such as conflict resolution strategies and children. The specific focus of this study was to determine how conflicts about money influences negative relationship outcomes.

Money Arguments. A couple's conflict resolution technique is a skill set that requires knowledge of specific spousal preferences and behaviors. Communication and conflict resolution tactics that work with one spouse are not guaranteed to work with another spouse. Arguing about money serves as an indicator that the couple has chosen not to invest resources into the 
relationship to increase spousal-specific capital. Marriage is often the first opportunity couples have to pool their resources with a joint utility function objective. The uncertainty associated with joint money management is quite high, so investment in marriage capital specifically related to unique interpersonal money issues can reduce the probability of divorce by decreasing the uncertainty associated with the marriage.

Other Spousal-Specific Investments. Other more commonly accepted spousal-specific factors include children and marital duration. Parental satisfaction from children has been found to be affected by timing of births, gender of children, and parenting skills (Bradbury, Fincham, \& Beach, 2000). Recent research by Gorchoff, John, and Helson (2008) indicates that marital satisfaction decreases after the birth of children but increases again after the children leave the home. Married couples who bear their own children (compared to adopting) have a reduced risk of divorce (de Graaf \& Klamijn, 2006), whereas bringing children from prior relationships into the marriage has the opposite effect (Becker, 1981; Markman, Stanley, \& Blumberg, 2001). Spousal Search Activity

Spousal search activity refers to dating behaviors before marriage, including length of dating and the quality of information transferred during the dates. Knowing each other for a short period of time and young age at marriage are risk factors for divorce (Markman et al., 2001). Couples can increase their chances of experiencing positive relationship outcomes by engaging in premarital counseling, although education of more than 10 hours does not seem to increase relationship satisfaction significantly more than shorter premarital education programs (Stanley, Amato, Johnson, \& Markman, 2006).

Assortative Mating 
Positive assortative mating occurs when spouses marry one another based on similar characteristics. Couples who engage in positive assortative mating tend to be more consumption focused. Couples who engage in negative assortative mating marry based on the comparative advantage each spouse can bring to the relationship and tend to be more production focused (Becker, 1976). According to Becker, positive assortative mating results in greater expected gains from marriage with the exception of income levels of spouses where negative assortative mating is preferred. Other researchers agree that spouses with similar backgrounds share more interests and values and tend to report higher relationship satisfaction (Luo \& Klohnen, 2005; Rick, Small, \& Finkel, 2009). According to Brown, Sanchez, Nock, and Wright, 2006, spouses have an increased risk of divorce when they are six or more years apart in age, four or more years apart in educational attainment, or are of a different race or religion. In contrast, Watson, Klohnen, Casillas, Simms, Haig, and Berry (2004) found that husbands reported greater relationship satisfaction when wives were of a dissimilar age, though wives' relationship satisfaction was not affected by her husband's age.

The literature on the effect of income differences on marriage outcomes is mixed. One group has found evidence that when women increase their income, marital instability increases, although the effect has been declining in recent decades with less emphasis on traditional marriage expectations (Ressler \& Waters, 2000; Tzeng \& Mare, 1995; Zagorsky, 2005). In contrast, Deutsch, Roksa, and Meeske (2003) found that women and men experience more positive feelings when either spouse increases their income even when women out earn their husbands. Still other research suggests that the likelihood of divorce is highest when wives contribute $40-50 \%$ to household income with an inverted U-shape function for lower and higher levels of contributions to household income (Rogers, 2004). According to Rogers, the 
result was explained by wives' decreased economic dependence on their husbands and a lower level of spousal specialization in household responsibilities.

\section{Summary}

As illustrated in Equation 3, spousal-specific investments, spousal search activity, and assortative mating (positive and negative) influence the amount $[E(G)]$ and/or the variance distribution $[\operatorname{Var}(G)]$ of expected net gains from marriage. It is hypothesized that lower $E(G)$ and higher $\operatorname{Var}(G)$ are associated with an increased likelihood of a negative relationship outcome (i.e., low relationship satisfaction or divorce).

Likelihood of Negative Relationship Outcome $=f$ [spousal-specific investments, spousal search activity, assortative mating]

\section{Methods}

\section{Data}

The National Longitudinal Survey of Youth 1979 (NLSY79), sponsored by the Bureau of Labor Statistics, is a nationally representative sample of 12,686 individuals first surveyed in 1979 when they were between the ages of 14 and 22. Respondents were surveyed every year until 1994 and have been surveyed every other year since then. Relationship satisfaction, frequency of money arguments, and variables that can serve as proxies for the conceptual model are available in the NLSY79, which makes it an ideal data set for this study. One of the independent variables of interest (i.e., frequency of money arguments) was only asked of female respondents. Therefore, the respondents used in this study were limited to married women in their first marriage. It is possible that individuals in remarriages will behave differently than those in their first marriages, which was not the focus of the current study.

\section{Dependent Variables}


Negative relationship outcomes were first measured by the following indicator of relationship satisfaction: "Would you say that your relationship/marriage is very happy, fairly happy, or not too happy?" The distribution of the current sample was very happy $(n=447)$, fairly happy $(\mathrm{n}=242)$, and not too happy $(\mathrm{n}=28)$. For the testing procedures, fairly happy and not too happy were combined to classify a couple as not too satisfied (1) or very satisfied (0). In the second model, the dependent variable measures negative relationship outcome in the form of divorce where $1=$ divorced and $0=$ remained married to first spouse.

\section{Independent Variables}

Spousal-Specific Investments. Of interest to the current study was the spouse's investment in spousal-specific capital related to frequency of money arguments. Females were asked to indicate how often they argued about money with their spouse where $1=$ often, $2=$ sometimes, 3 $=$ hardly ever, and $4=$ never in the original NLSY79 data set. The item was reverse coded so a higher number represented more frequent arguments. Initial investment in capital related to money issues were proxied with the level of arguments about money taken from the closest survey year the money arguments question was asked (i.e., 1988, 1992, 1994, 1996, 1998, 2000, 2002, 2004, and 2006) and the year the couple was married. The two middle categories of sometimes and hardly ever were combined and represent the reference group. Spouses who always argued about money when they were first married were hypothesized to report lower relationship satisfaction in 2006 and spouses who never argued about money when they were first married were hypothesized to report higher relationship satisfaction in 2006 compared to those who reported to sometimes or hardly ever argue about money in the early years of marriage. Three categories were created to capture the variance in expectations related to money arguments: (a) money arguments decreased during marriage, (b) money arguments stayed the 
same (reference group), and (c) money arguments increased during marriage. When money arguments decrease, relationship satisfaction is expected to be higher and when money arguments increase, relationship satisfaction is expected to be lower.

To capture if a couple argues about all areas of their relationship, rather than solely money issues, 10 topics of conflict (i.e., chores, children, money, affection, religion, leisure time, drinking, own relatives, in-laws, other women) were summed to form a new variable called "general arguing ${ }^{1}$." As with money arguments, the original scoring was reversed so that a higher score represents more frequent arguing. The frequency of general arguing at marriage was measured on a continuous basis (a summed score does not allow for the same categories of never, sometimes/hardly ever, and often arguing used for frequency of money arguments). Couples with more frequent arguments at marriage were hypothesized to report lower relationship satisfaction. To capture the variance in general arguing, couples were considered to argue the same amount at both data points if their score was within two points, which resulted in a similar frequency distribution as money arguments. The variance in general arguing was measured similar to money arguments where (a) general arguing decreased during marriage, (b) general arguing stayed about the same (reference group), and (c) general arguing increased during marriage. As with money arguments, an increase in frequency of general arguing was hypothesized to be associated with a negative relationship outcome.

If respondents had children living in the household during the year they were married, they were coded as 1 , otherwise 0 , to proxy non-spousal-specific investment since the children could be from another relationship or from the current relationship, but unplanned. These

\footnotetext{
${ }^{1}$ Respondents were not asked to indicate their frequency of arguments about their own relatives in 1988, so the frequency couples argued about in-laws in 1988 was counted twice to maintain the same range of 10-40 for couples married at different points in time. This method was chosen because of the high correlation of the items in the 1992 survey $(r=.61, p<.001)$.
} 
households were hypothesized to report a negative relationship outcome in 2006. If respondents had children living in the household in 2006, it is more likely that the children were brought into the home jointly by the couple. These households were coded as 1 if they had children in 2006, otherwise 0 and were hypothesized to report a positive relationship outcome.

The final measure of spousal-specific investments was marital duration, measured on a continuous basis. Couples with longer marital durations were hypothesized to be making investments in spousal-specific capital, which is associated with positive relationship outcomes.

Spousal Search Activities. Spousal search activity represents the amount of time spent looking for the most satisfying spouse. Length of courtship data is not available in the NLSY79, so age at marriage, measured continuously, served as a proxy for search behaviors of respondents. Although age at marriage may also represent maturity level of partners, age at marriage is the best available proxy for search behavior in the current data set. Search is a concept that occurs before marriage, so variance in search factors was not measured.

Assortative Mating. Couples who engage in positive assortative mating are thought to marry based on consumption-focused activities, which were operationalized with age and education differences between spouses. Respondents within five years of age from one another were coded 1, otherwise 0 (modeled after the work of Brown, Sanchez, Nock, and Wright, 2006). Couples with the same educational level (i.e., less than 12 years, 12 years, 13-15 years, 16 years, or more than 16 years) at marriage were coded 1 , otherwise 0 . Spouses of similar age and education were hypothesized to report positive relationship outcomes. Changes in educational level were indicated by 1 if either the respondent or the spouse moved to a different educational category or by 0 if they remained in the same educational category. Variance in expectations is 
associated with reduced relationship satisfaction; therefore, change in education was hypothesized to have a negative effect on marriages.

Couples who engage in negative assortative mating tend to be more focused on maximizing production of household and market goods (e.g., home good meals and money). To maximize household production, one spouse will specialize in market work (traditionally the husband) and the other in household work (traditionally the wife). To account for expected gains related to negative assortative mating, three income contribution levels at marriage were created based on sex: (a) female contributes less than $40 \%$ to household income, (b) female contributes $40 \%-60 \%$ to household income (reference group), or (c) female contributes more than $60 \%$ to household income (modeled after the work of Jianakoplos and Bernasek, 2008). It was hypothesized that when women contribute less than $40 \%$ to household income, relationship satisfaction will be higher and relationship satisfaction will be lower when women contribute more than $60 \%$ to household income because husbands and wives lose their comparative advantage in market work and household work, respectively. Next, three categorical variables were created to determine the variance in income levels by measuring if: (a) spouses continued to contribute the same percent to household income (reference group), (b) the female increased her income contribution, or (c) the male increased his income contribution. Similar to level of gains expected, increases in female income were hypothesized to result in negative relationship outcomes whereas increases in male income were hypothesized to reduce negative relationship outcomes.

A household income effect may influence marital stability as noted by Liu and Vikat (2007). They found that couples with lower levels of household income were at an increased risk for marital instability. Household income at marriage and changes in household income from 
marriage until 2006 (both measured by quartiles) were included in the regression to control for the income effect. All incomes were inflated to 2006 dollars to control for the effect of inflation on incomes gathered from several different time periods. Hypothesized effects for all variables are shown in Table 1. 
Table 1

Hypothesized Effects on Negative Relationship Outcomes

Variable

Spousal-Specific Investments

Arguments about money at marriage

Changes in arguments about money

General arguing at marriage

Changes in general arguing

Children prior to marriage

Children during marriage

Marital duration

Spousal Search Activity

Age at marriage

Assortative Mating

Same age

Same education

Changes in education

Income at marriage (wife earn more)

Income at marriage (husband earn more)

Changes in income (wife earn more)

Changes in income (husband earn more)

\section{Hypothesized Hypothesized \\ Level Variance}

$+$

$+$

$+$

$+$

$-$

$-$

$-$

$+$

$+$

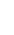




\section{Results}

The relationship satisfaction sample $(\mathrm{N}=717)$ consisted of married women who answered the questions of interest in the survey year closest to their marriage and in 2006, whereas the divorce sample $(\mathrm{N}=966)$ consisted of women who answered the questions of interest in the survey year closest to their marriage and the year they divorced or in 2006 if they were still married, resulting in a larger sample size than the relationship satisfaction sample. Descriptive statistics for the relationship satisfaction sample are shown in Table 2. Descriptive statistics for the divorce sample are shown in Table 3.

\section{Descriptive Statistics of the Relationship Satisfaction Sample}

Thirty-eight percent of the sample reported that they were only fairly or not too happy with their marriage and $62 \%$ reported that they were very happy with their marriage when asked in 2006. Women reported, on average, to hardly ever or sometimes $(\mathrm{M}=2.4)$ argue about money with their spouse when asked in the early years of their marriage. Twenty-eight percent of the sample reported a decrease in their frequency of money arguments, $45 \%$ reported no change in their level of money arguments, and $27 \%$ reported an increase in their frequency of money arguments. The average frequency of general arguing at marriage was 19 with a range of $10-$ 35. Thirty-four percent of the sample reported a decrease in their frequency of general arguing, $40 \%$ reported no change, and 26\% reported an increase in their frequency of general arguing.

The average marital duration was 21 years with a range of less than 1 year to 33 years. A smaller proportion of the sample had children before marriage than during marriage, as measured in 2006 (18\% and 80\%, respectively). Respondents' mean age at marriage was 24 with a range of 13 to 46 . Spouses' mean age at marriage was 27 with a range of 15 to 64 . Approximately $16 \%$ of 
the sample was six or more years older or younger than their spouse and $84 \%$ of the sample was within five years of age from one another.

The majority of the sample had at least 12 years of education at marriage. Forty-five percent of the sample shared the same educational category (i.e., less than 12 years, 12 years, 13 - 15 years, 16 years, or more than 16 years) at marriage; most did not attain more education prior to $2006(70 \%)$. Over half of the wives in the sample (58\%) contributed less than $40 \%$ to household income. Thirty-one percent of females contributed about the same percent to household income as their spouses and the remaining $10 \%$ contributed more than $60 \%$ to household income. Fifty-two percent did not experience changes in their income contribution, $28 \%$ of females increased their income contribution, and $20 \%$ of males increased their income contribution. 
Table 2

Descriptive Statistics for Relationship Satisfaction Sample $(\mathrm{N}=717)$

\begin{tabular}{|c|c|c|}
\hline Variable & At marriage & 2006 \\
\hline \multicolumn{3}{|l|}{ Relationship Satisfaction } \\
\hline Very happy (0) & & $62.34 \%$ \\
\hline Fairly happy/Not too happy (1) & & $37.66 \%$ \\
\hline \multicolumn{3}{|l|}{ Spousal-Specific Investments } \\
\hline Arguments about money at marriage & $\mathrm{M}=2.39$ & $\mathrm{M}=2.35$ \\
\hline Never (1) & $22.04 \%$ & $19.67 \%$ \\
\hline Hardly Ever (2) & $31.10 \%$ & $36.26 \%$ \\
\hline Sometimes (2) & $32.91 \%$ & $33.75 \%$ \\
\hline Often (3) & $13.95 \%$ & $10.32 \%$ \\
\hline Change in money arguments & $\mathrm{N} / \mathrm{A}$ & \\
\hline Money arguments decreased (1) & & $28.45 \%$ \\
\hline Money arguments stayed the same (2) & & $44.63 \%$ \\
\hline Money arguments increased (3) & & $26.92 \%$ \\
\hline General arguing at marriage & $M=19.05 R=10-35$ & $\mathrm{M}=18.39 \mathrm{R}=10-33$ \\
\hline Change in general arguing & N/A & \\
\hline General arguing decreased (1) & & $34.17 \%$ \\
\hline General arguing stayed the same (2) & & $40.17 \%$ \\
\hline General arguing increased (3) & & $25.66 \%$ \\
\hline Children & $\mathrm{M}=0.34 \mathrm{R}=0-5$ & $\mathrm{M}=1.74 \mathrm{R}=0-10$ \\
\hline Children in household (1) & $17.99 \%$ & $80.47 \%$ \\
\hline No children in household $(0)$ & $82.01 \%$ & $19.53 \%$ \\
\hline Marital duration & N/A & $\mathrm{M}=20.90 \mathrm{R}=0-33$ \\
\hline \multicolumn{3}{|l|}{ Spousal Search Activities } \\
\hline Respondent age at marriage & $M=24.01 R=13-46$ & $\mathrm{~N} / \mathrm{A}$ \\
\hline Spouse age at marriage & $M=27.05 \quad R=15-64$ & \\
\hline \multicolumn{3}{|l|}{ Assortative Mating } \\
\hline Within 5 years of age of each other (1) & $84.07 \%$ & $\mathrm{~N} / \mathrm{A}$ \\
\hline Not within 5 years of age $(0)$ & $15.20 \%$ & \\
\hline Same education at marriage (1) & $44.91 \%$ & $\mathrm{~N} / \mathrm{A}$ \\
\hline Different education at marriage $(0)$ & $55.09 \%$ & \\
\hline One/both increased education (1) & $\mathrm{N} / \mathrm{A}$ & $30.40 \%$ \\
\hline No changes in education $(0)$ & & $69.60 \%$ \\
\hline Wife earns $<40 \%$ of $\mathrm{HH}$ income at marriage (1) & $58.44 \%$ & N/A \\
\hline Wife earns $40-60 \%$ of $\mathrm{HH}$ income at marriage (2) & $31.24 \%$ & \\
\hline Wife earns $>60 \%$ of $\mathrm{HH}$ income at marriage (3) & $10.32 \%$ & \\
\hline No changes in income (1) & $\mathrm{N} / \mathrm{A}$ & $52.16 \%$ \\
\hline Wife increased income (2) & & $27.62 \%$ \\
\hline Husband increased income (3) & & $20.22 \%$ \\
\hline \multicolumn{3}{|l|}{ Income Effect Control } \\
\hline Level of household income at marriage & & $\mathrm{N} / \mathrm{A}$ \\
\hline Quartile $1(\$ 0$ - \$27,999) & $25 \%$ & \\
\hline Quartile $2(\$ 28,000-\$ 47,999)$ & $25 \%$ & \\
\hline Quartile $3(\$ 48,000$ - $\$ 76,849)$ & $25 \%$ & \\
\hline Quartile $4(\$ 76,850$ - $\$ 394,905)$ & $25 \%$ & \\
\hline Level of household income changes & $\mathrm{N} / \mathrm{A}$ & \\
\hline Quartile $1(-\$ 380,505--\$ 3,680)$ & & $25 \%$ \\
\hline Quartile $2(-\$ 3,679-\$ 18,999)$ & & $25 \%$ \\
\hline Quartile $3(\$ 19,000-\$ 50,649)$ & & $25 \%$ \\
\hline Quartile $4(\$ 50,650$ - $\$ 560,986)$ & & $25 \%$ \\
\hline
\end{tabular}




\section{Descriptive Statistics of the Divorced Sample}

As of $2006,24 \%$ of the wives who responded to the questions of interest in the early years of marriage were divorced and $76 \%$ were still married to their first spouse. As with the relationship satisfaction sample, the average frequency of money arguments in the early years of marriage was 2.4. The change in frequency of money arguments at divorce (or 2006) was also similar to the relationship satisfaction sample, with $27 \%$ of the sample reporting a decrease in money arguments, exactly half reporting the same level of money arguments, and $22 \%$ reporting an increase in their frequency of money arguments. The average frequency of general arguing at marriage was 19.2 (possible range of $10-40$ ) with $32 \%$ reporting a decrease, $46 \%$ reporting no change, and $22 \%$ reporting an increase in general arguing.

The average marital duration for the divorced sample was 18.5 years, which is .5 years shorter than the relationship satisfaction sample, with a range of less than 1 year to 33 years. The mean number of children in the household at marriage was .3 with a range of 0 to 5 ; the mean number of children in the household at the second data point (2006 if the respondent was still married or the year of divorce) was 1.7 with a range of 0 to 10 . Respondents and their husbands in the divorced sample married, on average, one year earlier (23 and 26, respectively) than the respondents and husbands in the relationship satisfaction sample. Approximately $83 \%$ of the sample was within five years of age from one another and $17 \%$ of the sample was six or more years older or younger than their spouse.

Approximately $46 \%$ of spouses had the same level of education (i.e., less than 12 years, 12 years, 13 - 15 years, 16 years, or more than 16 years) at marriage and $29 \%$ had moved to a different educational category by divorce (or 2006 if they did not divorce). The majority of the female respondents (62\%) contributed less than $40 \%$ to household income. Twenty-nine percent 
of respondents contributed between $40 \%$ to $60 \%$ to household income and $9 \%$ contributed more than $60 \%$ to household income. Half of the household (50\%) did not experience changes in their income structure, $27 \%$ of wives increased their income, $18 \%$ of husbands increased their income, and $5 \%$ of the sample had missing income data. To retain a larger sample size in the regression analysis, respondents with missing income data were combined with those who reported no changes in their income. 
Table 3

Descriptive Statistics for Divorced Sample $(\mathrm{N}=966)$

\begin{tabular}{|c|c|c|}
\hline Variable & At marriage & At divorce/2006 \\
\hline \multicolumn{3}{|l|}{ Marital Status } \\
\hline Married (0) & $100.00 \%$ & $76.40 \%$ \\
\hline Divorced (1) & & $23.60 \%$ \\
\hline \multicolumn{3}{|l|}{ Spousal-Specific Investments } \\
\hline Money arguments at marriage & $\mathrm{M}=2.40$ & $\mathrm{M}=2.31$ \\
\hline Never (1) & $22.05 \%$ & $22.57 \%$ \\
\hline Hardly Ever/Sometimes (2) & $30.33 \%$ & $34.78 \%$ \\
\hline Sometimes (2) & $32.92 \%$ & $31.47 \%$ \\
\hline Often (3) & $14.70 \%$ & $11.18 \%$ \\
\hline Change in frequency of arguments & N/A & \\
\hline Money arguments decreased (1) & & $27.23 \%$ \\
\hline Money arguments are same (2) & & $50.41 \%$ \\
\hline Money arguments increased (3) & & $22.36 \%$ \\
\hline General arguing at marriage & $M=19.20 R=10-40$ & $\mathrm{M}=18.33 \mathrm{R}=10-39$ \\
\hline \multicolumn{3}{|l|}{ Change in general arguing } \\
\hline General arguing decreased (1) & & $31.99 \%$ \\
\hline General arguing are same (2) & & $45.96 \%$ \\
\hline General arguing increased (3) & & $22.05 \%$ \\
\hline Children & $\mathrm{M}=0.34$ Range $=0-5$ & $M=1.67$ Range $=0-10$ \\
\hline Children in household (1) & $18.53 \%$ & $78.36 \%$ \\
\hline No children in household $(0)$ & $81.47 \%$ & $21.64 \%$ \\
\hline Marital duration & N/A & $\mathrm{M}=18.54$ Range $=0-33$ \\
\hline \multicolumn{3}{|l|}{ Spousal Search Activity } \\
\hline Respondent age at marriage & $\mathrm{M}=23.07$ Range $=13-46$ & $\mathrm{~N} / \mathrm{A}$ \\
\hline Spouse age at marriage & $\mathrm{M}=26.34$ Range $=15-64$ & \\
\hline \multicolumn{3}{|l|}{ Assortative Mating } \\
\hline Within 5 years of age of each other (1) & $82.71 \%$ & $\mathrm{~N} / \mathrm{A}$ \\
\hline Not within 5 years of age $(0)$ & $17.29 \%$ & \\
\hline Same education at marriage (1) & $46.17 \%$ & N/A \\
\hline Different education at marriage $(0)$ & $53.83 \%$ & \\
\hline One/both increased education (1) & $\mathrm{N} / \mathrm{A}$ & $29.40 \%$ \\
\hline No changes in education $(0)$ & & $70.60 \%$ \\
\hline Wife earns $<40 \%$ of $\mathrm{HH}$ income at marriage (1) & $61.80 \%$ & N/A \\
\hline Wife earns $40-60 \%$ of $\mathrm{HH}$ income at marriage (2) & $29.09 \%$ & \\
\hline Wife earns $>60 \%$ of $\mathrm{HH}$ income at marriage (3) & $9.11 \%$ & \\
\hline No changes in income (1) & N/A & $50.41 \%$ \\
\hline Wife increased income (2) & & $26.50 \%$ \\
\hline Husband increased income (3) & & $17.60 \%$ \\
\hline Missing information (1) & & $5.49 \%$ \\
\hline \multicolumn{3}{|l|}{ Income Effect Control } \\
\hline Level of income at marriage & & N/A \\
\hline Quartile $1(\$ 0-\$ 26,054)$ & $25 \%$ & \\
\hline Quartile $2(\$ 26,055$ - $\$ 44,199)$ & $25 \%$ & \\
\hline Quartile $3(\$ 44,200$ - \$70,399) & $25 \%$ & \\
\hline Quartile $4(\$ 70,400-\$ 394,905)$ & $25 \%$ & \\
\hline Level of income changes & N/A & \\
\hline Quartile $1(-\$ 380,505--\$ 1,401)$ & & $25 \%$ \\
\hline Quartile $2(-\$ 1,400-\$ 16,799)$ & & $25 \%$ \\
\hline Quartile $3(\$ 16,800$ - \$45,499) & & $25 \%$ \\
\hline Quartile $4(\$ 45,500-\$ 560,986)$ & & $25 \%$ \\
\hline
\end{tabular}




\section{Logistic Regressions}

An unweighted logistic regression was used to predict low relationship satisfaction for model 1 (Table 4) and the likelihood of divorce in model 2 (Table 5). Logistic regression was chosen due to the dichotomous nature of the dependent variables [i.e., low (1) versus high (0) relationship satisfaction and did respondents divorce (1) or remain married (0)]. The Log Likelihood Ratio was statistically significant for both models at the $p<.001$ level (118.92 and 754.40 for models 1 and 2, respectively).

\section{Model 1 Results - Predicting Low Relationship Satisfaction}

With the exception of decreased money arguments throughout the duration of one's marriage, all other money arguments showed significance in the direction predicted and were the top contributors to the model (see $\beta$ column in Table 4). Respondents who reported often arguing about money were nearly two and a half times more likely to experience reduced relationship satisfaction later in marriage (odds ratio $=2.38, p<.01$ ), whereas respondents who reported never arguing about money were $53 \%$ less likely to experience low relationship satisfaction later in marriage (odds ratio $=.47, p<.01$ ) compared to those who sometimes or hardly ever argued about money. A decrease in money arguments did not have a statistically significant influence on relationship satisfaction; however, an increase in money arguments during marriage was significantly related to lower relationship satisfaction (odds ratio $=2.44, p<.001$ ).

As with arguments specific to money, wives who reported arguing about many topics (i.e., general arguing) in the early years of marriage reported lower relationship satisfaction in the later years of their marriage. There was an inverse relationship satisfaction with relationship satisfaction and changes in general arguing with a decrease in general arguing being associated with increased relationship satisfaction (odds ratio $=.55, p<.05$ ) and an increase in general 
arguing being associated with decreased relationship satisfaction (odds ratio $=1.91, p<.01$ ) compared to no changes in the level of general arguing as reported by wives.

No other variables designed to measure spousal-specific investments (i.e., children and marital duration) and spousal search activities (i.e., respondent age at marriage) were significant predictors of low relationship satisfaction. Support for negative assortative mating was found with the income change variable where an increase in wives income throughout the duration of marriage was associated with a decrease in wives' relationship satisfaction (odds ratio $=1.66, p$ $<.05)$. 
Table 4

Model 1 Results - Predicting Low Relationship Satisfaction

\begin{tabular}{|c|c|c|c|}
\hline Variable & b & OR & $\beta$ \\
\hline Intercept & -1.4557 & & \\
\hline \multicolumn{4}{|l|}{ Spousal-Specific Investments } \\
\hline \multicolumn{4}{|c|}{ Money arguments at marriage (reference $=$ sometimes/hardly ever) } \\
\hline Never & $-0.75^{* *}$ & 0.47 & -0.17 \\
\hline Often & $0.87 * *$ & 2.38 & 0.17 \\
\hline \multicolumn{4}{|l|}{ Change in money arguments (reference $=$ same) } \\
\hline Money arguments decreased & 0.06 & 0.94 & -0.02 \\
\hline Money arguments increased & $0.89 * * *$ & 2.44 & 0.22 \\
\hline General arguing at marriage & $0.11 * * *$ & 1.11 & 0.30 \\
\hline \multicolumn{4}{|l|}{ Change in general arguing (reference $=$ same) } \\
\hline General arguing decreased & $-0.59 *$ & 0.55 & -0.15 \\
\hline General arguing increased & $0.65 * *$ & 1.91 & 0.16 \\
\hline Children prior to marriage & 0.20 & 1.22 & 0.04 \\
\hline Children after marriage & -0.07 & 0.94 & -0.01 \\
\hline Marital duration & -0.03 & .97 & -0.12 \\
\hline \multicolumn{4}{|l|}{ Spousal Search Activities } \\
\hline Respondent age at marriage & -0.02 & 0.98 & -0.06 \\
\hline \multicolumn{4}{|l|}{ Assortative Mating } \\
\hline Same age (reference $=$ not within 5 years $)$ & -0.38 & 0.68 & -0.08 \\
\hline $\begin{array}{l}\text { Same education at marriage (reference }= \\
\text { different) }\end{array}$ & 0.29 & 1.33 & 0.08 \\
\hline Education changes (reference $=$ no changes) & 0.30 & 1.35 & 0.08 \\
\hline \multicolumn{4}{|c|}{ Income difference at marriage (reference $=$ wife earns $40-60 \%$ of $\mathrm{HH}$ income) } \\
\hline Wife earns $<40 \%$ of $\mathrm{HH}$ income & -0.20 & 0.82 & -0.06 \\
\hline Wife earns $>60 \%$ of $\mathrm{HH}$ income & 0.27 & 1.31 & 0.05 \\
\hline \multicolumn{4}{|l|}{ Income changes $($ reference $=$ no changes $)$} \\
\hline Wife increased income & $0.21 *$ & 1.66 & 0.12 \\
\hline Husband increased income & 0.22 & 1.25 & 0.05 \\
\hline \multicolumn{4}{|l|}{ Income Effect Control } \\
\hline \multicolumn{4}{|c|}{ Level of household income at marriage $($ reference $=$ quartile 4$)$} \\
\hline Quartile 1 & -0.30 & 0.66 & -0.10 \\
\hline Quartile 2 & -0.28 & 0.65 & -0.10 \\
\hline Quartile 3 & -0.26 & 0.65 & -0.10 \\
\hline \multicolumn{4}{|c|}{ Level of household income changes (reference $=$ quartile 4 ) } \\
\hline Quartile 1 & 0.08 & 1.09 & 0.02 \\
\hline Quartile 2 & 0.22 & 1.24 & 0.05 \\
\hline Quartile 3 & 0.08 & 1.08 & 0.02 \\
\hline \multicolumn{4}{|l|}{ Pseudo $\mathrm{R}^{2}=0.21$} \\
\hline \multicolumn{4}{|l|}{ Likelihood Ratio $=118.92 * * *$} \\
\hline$* p<.05, * * p<.01, * * * p<.001$ & & & \\
\hline
\end{tabular}




\section{Model 2 Results - Predicting Divorce}

The second logistic model was designed to assess whether the factors that predict low relationship satisfaction are the same as those that predict divorce, with a specific interest in how arguments about money influence divorce.

Spousal-Specific Investments. The variables representing spousal-specific investments had the greatest contribution to the model, as indicated by the standardized beta estimates. Specifically, marital duration was most predictive of whether a respondent divorced $(\beta=-2.94)$. The shorter the marital duration, the greater the likelihood of divorce (odds ratio $=.53, p<.001$ ). The third most predictive factor in the model was investment in children during marriage ( $\beta=$ .43 ). These respondents were approximately $85 \%$ less likely to divorce (odds ratio $=.15, p<$ .001). Having children prior to marriage did not significantly increase the likelihood of divorce. Respondents who reported often arguing about money at marriage were nearly three times more likely to divorce compared to those who sometimes or hardly ever argued about money (odds ratio $=2.62, p<.05$ ). This specific variable, within spousal-specific investments, was the fourth largest contributor to the model with a standardized beta estimate of .19. The level and variance of general arguing were not significant predictors of divorce.

Spousal Search Activity. The second most predictive variable in the model $(\beta=-2.66)$ was the variable used to proxy spousal search activity, age at marriage. Respondents who were younger when they married were more likely to divorce than respondents who were older when they married (odds ratio $=.46, p<.001$ ).

Assortative Mating. The only assortative mating variable that was statistically significant was the age difference variable, which had the fifth largest standardized beta estimate of -.19. Spouses of similar age were $59 \%$ less likely to divorce (odds ratio $=.41, p<.05$ ). 
Table 5

Model 2 Results - Predicting Divorce

\begin{tabular}{|c|c|c|c|}
\hline Variable & $\boldsymbol{b}$ & OR & $\boldsymbol{\beta}$ \\
\hline Intercept & 31.94 & & \\
\hline \multicolumn{4}{|l|}{ Spousal-Specific Investments } \\
\hline \multicolumn{4}{|c|}{ Money arguments at marriage (reference $=$ sometimes/hardly ever) } \\
\hline Never & -0.22 & 0.80 & -0.05 \\
\hline Often & $0.96^{*}$ & 2.62 & 0.19 \\
\hline \multicolumn{4}{|c|}{ Change in money arguments (reference $=$ stayed the same) } \\
\hline Money arguments decreased & -0.23 & 0.79 & -0.06 \\
\hline Money arguments increased & -0.36 & 0.70 & -0.08 \\
\hline General arguing at marriage & -0.06 & 0.94 & -0.18 \\
\hline \multicolumn{4}{|l|}{ Change in general arguing (reference $=$ stayed the same) } \\
\hline General arguing decreased & 0.23 & 1.26 & 0.06 \\
\hline General arguing increased & -0.38 & 0.69 & -0.09 \\
\hline Children prior to marriage & -0.02 & 0.99 & -0.00 \\
\hline Children during marriage & $-1.87 * * *$ & 0.15 & -0.43 \\
\hline Marital duration & $-0.64 * * *$ & 0.53 & -2.98 \\
\hline \multicolumn{4}{|l|}{ Spousal Search Activity } \\
\hline Respondent age at marriage & $-0.79 * * *$ & 0.46 & -2.66 \\
\hline \multicolumn{4}{|l|}{ Assortative Mating } \\
\hline Same age (reference $=$ not within 5 years) & $-0.90^{*}$ & 0.41 & -0.19 \\
\hline Same education at marriage (reference $=$ different) & -0.52 & 0.59 & -0.14 \\
\hline Education changes $($ reference $=$ no changes $)$ & -0.25 & 0.78 & -0.06 \\
\hline \multicolumn{4}{|l|}{$\begin{array}{l}\text { Income difference at marriage (reference }=\text { wife earns } \\
40-60 \% \text { of } \mathrm{HH} \text { income) }\end{array}$} \\
\hline Wife earns $<40 \%$ of $\mathrm{HH}$ income & 0.10 & 1.11 & 0.03 \\
\hline Wife earns $>60 \%$ of $\mathrm{HH}$ income & -0.10 & 0.90 & -0.02 \\
\hline \multicolumn{4}{|l|}{$\begin{array}{l}\text { Income changes }(\text { reference }=\text { no changes } / \text { missing } \\
\text { information) }\end{array}$} \\
\hline Wife increased income & -0.33 & 0.72 & -0.08 \\
\hline Husband increased income & -0.30 & 0.74 & -0.06 \\
\hline \multicolumn{4}{|l|}{ Income Effect Control } \\
\hline \multicolumn{4}{|l|}{ Level of income at marriage (reference $=$ quartile 4 ) } \\
\hline Quartile 1 & 0.39 & 1.48 & 0.09 \\
\hline Quartile 2 & 0.83 & 2.30 & 0.20 \\
\hline Quartile 3 & -0.01 & 0.99 & -0.00 \\
\hline \multicolumn{4}{|l|}{ Level of income changes (references $=$ quartile 4$)$} \\
\hline Quartile 1 & 0.13 & 1.14 & 0.03 \\
\hline Quartile 2 & 0.37 & 1.44 & 0.09 \\
\hline Quartile 3 & -0.01 & 0.99 & -0.00 \\
\hline \multicolumn{4}{|l|}{ Pseudo $\mathrm{R}^{2}=.82$} \\
\hline \multicolumn{4}{|l|}{ Likelihood Ratio $=754.40 * * *$} \\
\hline${ }^{*} \mathrm{p}<.05, * * \mathrm{p}<.01, * * * \mathrm{p}<.001$ & & & \\
\hline
\end{tabular}




\section{Discussion}

The results of the two regression analyses show that money arguments among spouses are predictive of negative relationship outcomes in the form of lower relationship satisfaction and increased likelihood of divorce. Note, however, that money arguments are much larger contributors to low relationship satisfaction than divorce. The only predictive measure of money arguments leading to divorce was a frequent level of arguments in the early years of marriage. In contrast, frequent money arguments in the early years of marriage and an increase in money arguments throughout the duration of marriage were predictive of low relationship satisfaction. Further, never arguing about money in the early years of marriage was statistically significant in predicting high relationship satisfaction in later years of marriage. Similar results were also found for general arguing in the prediction of low relationship satisfaction. A discussion of these and the other statistically significant results are presented below.

\section{Spousal-Specific Investments}

In both models predicting negative relationship outcomes, spousal-specific investments were the most important determinant. Nevertheless, the specific proxies for spousal-specific investments that showed statistical significance were different in the model predicting low relationship satisfaction and the model predicting divorce. When predicting relationship satisfaction, the argument variables (i.e., money and general arguing) were the only proxies for spousal-specific investments that showed statistical significance. The results of the modeling predicting divorce showed the common factors thought to impact the decision to divorce of having children at home and being married for a longer duration (both being associated with a lower likelihood of divorce) were more important in the decision to divorce than frequent arguing about money at the beginning of one's marriage. A possible explanation for the lower 
impact of money arguments in the decision to divorce was offered by Gottman and Levenson's (2000) research, which found that couples on the road to divorce tend to be detached and avoidant with one another and therefore experience reduced arguments. Couples arguing about money are therefore interpreted to be more invested in developing a solution to problems in the marriage.

\section{Spousal Search Activity}

Spousal search activity is only important in predicting divorce. Respondents who engaged in less of a search (were younger when they married) had an increased likelihood of divorce compared to those who spent greater time searching for a spouse. This implies that respondents who spent more time searching were more certain about their decision and had higher expected gains from the relationship. Younger people, or those who engaged in a less extensive search, are met with a high degree of uncertainty and will have lower expectations about the marriage and increased risk of divorce. Less spousal search activity was not associated with reduced relationship satisfaction, however. This implies that current investments in the marriage were more important in determining relationship satisfaction than past events. If a couple does divorce, perhaps they are less likely to recall the level of arguing involved leading up to the divorce making past decisions more important in the decision (e.g., demographic characteristics such as age at marriage, marital duration, and presence of children).

\section{Assortative Mating}

In accordance with recent literature (Rick et al., 2009), the results provide support for positive assortative mating, thus reducing the likelihood of a negative relationship outcome. Support for this possibility was found in the form of age difference; spouses close in age were less likely to divorce. This suggests that spouses of similar age share interests which increases 
household utility and therefore the couples have less reason to divorce. The results associated with the relationship satisfaction regression show that when wives' income increases to the point of equaling or exceeding her husbands, her relationship satisfaction falls. This also confirms recent literature that negative assortative mating (particularly a man outearning the wife) is not as important in predicting satisfaction within the marriage as it once was (e.g., Deutsch et al., 2003).

\section{Conclusion}

This study provides particular value to the current body of knowledge related to marital outcomes with the finding that among the two models of negative relationship outcomes, the predictors of low relationship satisfaction are not the same as the predictors of divorce. Specifically, money arguments are highly predictive of low relationship satisfaction and only mildly predictive of divorce. Other researchers have also found that the predictors of high relationship satisfaction and divorce are not simply opposites (e.g., Bradbury et al., 2000) and that financial issues are a more commonly reported problem in relation to reduced relationship satisfaction than they are a reason for divorce (e.g., Albrecht, 1979). Results from this study should be interpreted with caution because the NLSY79 data set only asked the money argument variables of women. Alternative data sets may allow for men and women to be compared on their frequency of money arguments and the likelihood of divorce. However, as noted by Amato and Rogers (1997), women are more likely to report reasons for negative relationship outcomes, whereas men do not seem to know the reason or are not reporting it meaning that sampling women only may not be quite as problematic as it may initially seem.

In this study, it was illustrated that money arguments can be conceptualized as a spousalspecific investment within Becker's (1976) theories of marriage and divorce. Those who are less 
likely to experience a negative relationship outcome are those who invest in the marriage knowing that their investment is not transferable to another relationship. It is possible that early investments in knowledge of spousal money preferences are especially important in predicting relationship satisfaction. It is possible that money arguments are not as predictive of divorce as they are in relationship satisfaction because spouses nearing divorce have lost the desire to try to work through their relationship problems.

The implications for policy include incorporating financial counseling into required premarital counseling sessions for couples. Several of the predictors of divorce occur prior to marriage or in the early years of marriage, suggesting other areas of importance to discuss in a premarital counseling. For instance, premarital counselors can use the results to explain that getting married at an older age to a spouse of similar age may predict a lower likelihood of divorce. Of particular interest to this study is that investing in financially-based premarital counseling may reduce the likelihood of divorce by resolving arguments about how money will be used in the household. Couples who develop a working agreement on financial matters at the beginning of their marriage are predicted to have higher relationship satisfaction throughout their marriage. This may, in turn, result in lower rates of divorce if couples are more satisfied with their marriage. 


\section{References}

Amato, P. R. (2000). The consequences of divorce for adults and children. Journal of Marriage and the Family, 62(4), 1269-1287.

Amato, P. R., \& Previti, D. (2003). People's reasons for divorcing: Gender, social class, the life course, and adjustment. Journal of Family Issues, 24(5), 602-626.

Amato, P. R., \& Rogers, S. J. (1997). A longitudinal study of marital problems and subsequent divorce. Journal of Marriage and the Family, 59(3), 612-624.

Becker, G. S. (1976). The economic approach to human behavior. Chicago: The University of Chicago Press.

Becker, G. S. (1981). A treatise on the family. Cambridge: Harvard University Press.

Bradbury, T. N., Fincham, F. D., \& Beach, R. H. (2000). Research on the nature and determinants of marital satisfaction: A decade in review. Journal of Marriage and the Family, 62(4), 964-980.

Brown, S. L., Sanchez, L. A., Nock, S. L., \& Wright, J. D. (2006). Links between premarital cohabitation and subsequent marital quality, stability, and divorce: A comparison of covenant versus standard marriages. Social Science Research, 35(2), 454-470.

Bryant, W. K., \& Zick, C. D. (2006). The economic organization of the household ( $2^{\text {nd }}$ ed.). Cambridge: Cambridge University Press.

de Graaf, P. M., \& Kalmijn, M. (2006). Change and stability in the social determinants of divorce: A comparison of marriage cohorts in the Netherlands. European Sociological Review, 22(5), 561-572.

Deutsch, F. M., Roksa, J., \& Meeske, C. (2003). How gender counts when couples count their money. Sex Roles, 48(7-8), 291-304. 
Dew, J. P. (2009, November). Financial issues as predictors of divorce. Paper presented at the annual conference of the National Council on Family Relations, San Francisco, CA.

Dolan, M. A., \& Hoffman, C. D. (1998). Determinants of divorce among women: A reexamination of critical influences. Journal of Divorce and Remarriage, 28(3/4), 97-106.

Gorchoff, S. M., John, O. P., \& Helson, R. (2008). Contextualizing change in marital satisfaction during middle age: An 18-year longitudinal study. Psychological Science, 19(11), 11941200.

Gottman, J. M., \& Levenson, R. W. (2000). The timing of divorce: Predicting when a couple will divorce over a 14-year period. Journal of Marriage and the Family, 62(3), 737-745.

Jianakoplos, N. A., \& Bernasek, A. (2008). Family financial risk taking when the wife earns more. Journal of Family and Economic Issues, 29(2), 289-306.

Liu, G., \& Vikat, A. (2007). Does divorce risk in Sweden depend on spouses' relative income? A study of marriages from 1981 to 1998. Canadian Studies in Population, 34(2), 217-240.

Markman, H. J., Stanley, S. M., \& Blumberg, S. L. (2001). Fighting for your marriage: Positive steps for preventing divorce. San Francisco: Jossey-Bass.

Ressler, R. W., \& Waters, M. S. (2000). Female earnings and the divorce rate: A simultaneous equations model. Applied Economics, 32(14), 1889-1898.

Rick, S. I., Small, D. A., \& Finkel, E. J. (2009, September 30). Fatal (fiscal) attraction: Spendthrifts and tightwads in marriage. Retrieved from http://ssrn.com/abstract=1339240.

Risch, G. S., Riley, L. A., \& Lawler, M. G. (2003). Problematic issues in the early years of marriage: Content for premarital education. Journal of Psychology and Theology, 31(3), 253-269. 
Rogers, S. J. (2004). Dollars, dependency, and divorce: Four perspectives on the role of wives' income. Journal of Marriage and Family, 66(1), 59-74.

Stanley, S. M., Amato, P. R., Johnson, C. A., \& Markman, H. J. (2006). Premarital education, marital quality, and marital stability: Findings from a large, random household survey. Journal of Family Psychology, 20(1), 117-126.

Stanley, S. M., Markman, H. J., \& Whitton, S. W. (2002). Communication, conflict, and commitment: Insights on the foundations of relationship success from a national survey. Family Process, 41(4), 659-675.

Tzeng, J. M., \& Mare, R. D. (1995). Labor market and socioeconomic effects on marital stability. Social Science Research, 24(3), 329-351.

Watson, D., Klohnen, E. C., Casillas, A., Simms, E. N., Haig, J, \& Berry, D. S. (2004). Match makers and deal breakers: Analyses of assortative mating in newlywed couples. Journal of Personality, 72(5), 1029-1068.

White, L. K. (1990). Determinants of divorce: A review of research in the eighties. Journal of Marriage and the Family, 52(4), 904-912.

Zagorsky, J. L. (2003). Husbands' and wives' view of the family finances. Journal of SocioEconomics, 32(2), 127-146.

Zagorsky, J. L. (2005). Marriage and divorce's impact on wealth. Journal of Sociology, 41(4), 406-424. 